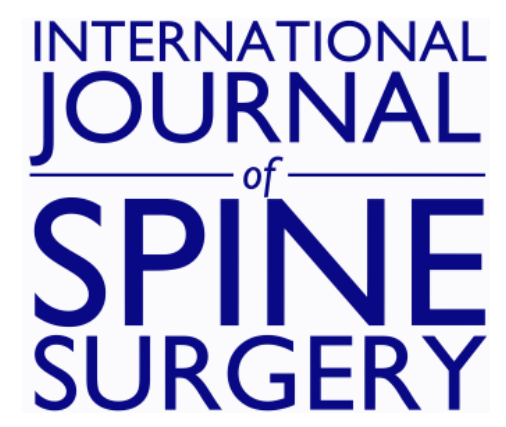

\title{
Adjacent disc height reduction and clinical outcome after intradiscal cement leakage
}

Minjie Shen, Junjie Niu, Haifei Zhou, Qian Meng, Minfeng Gan and Huilin Yang

Int J Spine Surg 2016, 10 ()

doi: https://doi.org/10.14444/3034

http://ijssurgery.com/content/10/34

This information is current as of April 26, 2023.

Email Alerts Receive free email-alerts when new articles cite this article. Sign up at:

http://ijssurgery.com/alerts

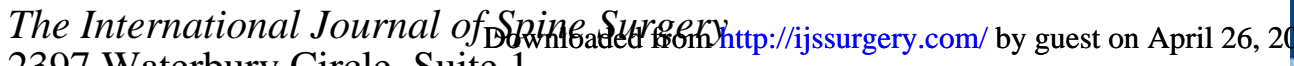
2397 Waterbury Circle, Suite 1,

Aurora, IL 60504, Phone: +1-630-375-1432

(C) 2016 ISASS. All Rights Reserved. 


\section{Adjacent disc height reduction and clinical outcome after intradiscal cement leakage}

Minjie Shen, Junjie Niu, Haifei Zhou, Qian Meng, Minfeng Gan, Huilin Yang, MD

First Affliated Hospital of Soochow University, Suzhou, China

\section{Abstract}

Objective

The purpose of this study is to evaluate the effect of intradiscal cement leakage on the height of adjacent cementcontaining discs and the resulting clinical efficacy after kyphoplasty.

Methods

A total of 124 patients were included and classified into two groups: group A included 20 patients with intradiscal leakage, and group B contained 104 patients without intradiscal leakage. The mean follow-up time was $20.56 \pm 3.51$ months. The height of the corresponding discs in both groups was measured using Farfan's method. Clinical efficacy was assessed using the Visual Analog Scale and Oswestry Disability Index scores at each follow-up time.

Results

The anterior disc height, posterior disc height and Farfan Index significantly decreased in both groups at last follow-up. The disc height reduction was $9.19 \pm 2.89 \%$ in group A and $3.88 \pm 2.70 \%$ in group B, which was significantly different between the groups $(\mathrm{P}<0.01)$. The disc height reduction rate was $29.39 \pm 7.90 \%$ in group $\mathrm{A}$ and $12.75 \pm 8.18 \%$ in group $B$, which was also a statistically significant difference $(\mathrm{P}<0.01)$. The VAS and ODI scores improved significantly after surgery and maintained at last follow-up, and there was no statistically significant difference between Groups A and B.

Conclusion

Intradiscal cement leakage was associated with the degeneration of cement-containing disc but did not reduce the clinical efficacy at early stages.

KEYWORDS: INTRADISCAL CEMENT LEAKAGE, DISC HEIGHT REDUCTION, CLINICAL EFFICACY, PERCUTANEOUS BALLOON KYPHOPLASTY VOLUME 10 ARTICLE 34 DOI: 10.14444/3034

\section{Introduction}

Vertebroplasty and kyphoplasty are minimally invasive techniques that are used to treat osteoporotic vertebral compression fractures. ${ }^{1,2}$ Cement leakage is a common complication of these techniques. According to Yeom's study, ${ }^{3}$ cement leaks through three pathways: via the basivertebral vein, via the segmental vein or via cortical defect. Through the cortical defect, the cement can leak into the adjacent discs. Although intradiscal cement leakage (IDL) is considered as a benign complication without any clinical symptoms, it has been identified as an important risk factor for subsequent fractures. ${ }^{5-11}$ However, the effect of IDL on the disc itself has not been reported. One preliminary study demonstrated that disc degeneration adjacent to the fractured vertebra was ac- celerated after vertebroplasty and kyphoplasty procedures compared with conservative treatment during two years of follow-up.

Disc height is a parameter that is known to be correlated with the degree of disc degeneration. Pfirrmann et al. ${ }^{12}$ demonstrated that disc height reduction was strongly associated with disc degeneration in elderly patients. In many previous studies, ${ }^{13-16}$ disc height measurements were adopted to evaluate adjacent disc degeneration in clinical studies and experiments. Disc height reduction was commonly observed after thoracolumbar fractures and associated with progressive local kyphosis and pain in patients who were treated conservatively or by open surgery. However, changes in the height of the adjacent disc, especially those with cement leakage, were previously un- 
known. In this study, we evaluated the effect of intradiscal cement leakage on the height of the adjacent cement-containing disc and the resulting clinical efficacy.

\section{Materials and Methods}

Patient Selection

We retrospectively analyzed 283 patients who were diagnosed with vertebral fractures (T11-L5) and underwent single level percutaneous balloon kyphoplasty (BKP) with polymethylmethacrylate (PMMA) in our institution from January 2008 to June 2011. Cement leakage from augmented vertebrae into adjacent discs was detected by postoperative radiographs and computed tomography (CT) scans.

Patients were excluded if they met any of the following criteria:

- Pathological vertebral fractures secondary to tumor or inflammation

- Contraindicated for MRI or presented with severe disc degeneration adjacent to fractured vertebra on preoperative MRI ( $\geq$ grade 6 according to modified Pfirrmann grading system)

- Presence of old fracture or previous augmentation at superior or inferior vertebra adjacent to painful vertebra

- Developed subsequent new fractures during follow-up

- Followed up for less than one year

Characteristics of the patients, including age, gender, $\mathrm{BMD}$, history of smoking and drinking, fracture age and fracture location, were recorded.

\section{Surgical Techniques}

Individualized BKP was carried out according to previously published techniques through a bilateral transpedicular approach using Kyphon (Sunnyvale, CA, USA) instruments and PMMA cement. For patients with endplate fracture, dynamic fluoroscopic monitoring by $\mathrm{C}$-arm was performed when cement was close to the fractured endplate. If IDL was noted, the injection was stopped immediately. After the cement was hardened for several minutes, the injection continued if the fractured vertebra was not ade- quately filled. The total volume of injected cement per vertebra was recorded. The patients were discharged one day after surgery.

\section{Radiological and Clinical Assessment}

All patients were followed up one day after surgery and at last follow-up. The results of radiological and clinical assessment were recorded.

The radiological examinations were performed by experienced radiologists. Anteroposterior and lateral radiographs were taken in standard supine position, and the X-ray beam was centered in the treated level. All image data were assessed by two radiologists (Q. M. and H.F.Z.) independently using the PACS imaging display software (Neusoft Inc., Shenyang, Chi$\mathrm{na}$ ), and the final decision was made by consensus. The fractured vertebrae were classified into one of three types: wedge, biconcave or crush. The severity of the fractured vertebra was graded as grade 1 ( $\leq$ $25 \%$ collapse), grade 2 (25\%-40\% collapse) or grade 3 ( $\geq 40 \%$ collapse). Endplate fracture was detected on preoperative MRI or three-dimensional reconstructive CT images. The presence of intravertebral cleft was defined as the presence of intravertebral fluid or air on the MRI. Using the method reported by Griffith et al., ${ }^{17}$ the preoperative degree of degeneration of superior discs adjacent to the fractured vertebrae in group $B$ and of the subsequent cement-containing discs in group A was classified into 8 grades according to the preoperative MRI.

The height of the cement-containing discs in group A was measured using Farfan's method. We chose the height measured one day after surgery as the baseline value. The shortest distances between the anterior and posterior edges of the neighboring endplates were measured on standard supine lateral radiographs and were recorded as the anterior disc height (Ha) and posterior disc height (Hp). The disc diameter (DM) was measured between the midpoints of the lines drawn from the endpoints of the superior vertebral endplate to the inferior (Figure 1). Then, the Farfan index was calculated as [( $\mathrm{Ha}+\mathrm{Hp}) /$ $\mathrm{DM}]^{*} 100 \%$. Disc height reduction (DHR) is the value of the Farfan index one day after surgery minus the Farfan index at last follow-up. DHR rate was expressed as DHR/baseline Farfan index*100\%. The 
height of superior discs adjacent to augmented vertebrae in group B was measured as control.

Clinical efficacy was assessed using visual analog scale (VAS) (on a scale of 0-10; 0-no pain, 10-worst pain) and Oswestry Disability Index (ODI) scores for pain and functional assessment.

\section{Statistical Analysis}

Statistical analysis was performed with SPSS version 19.0 software (SPSS, Inc, Chicago, IL, USA). A Pvalue less than 0.05 was considered statistically significant. The differences in the characteristics of patients and fractured vertebrae, total cement volume and baseline corresponding disc parameters were analyzed using a t-test or Mann-Whitney $U$ test for continuous variables and a Chi-square test for categorical variables.

The changes in the Ha, Hp and Farfan indexes, VAS and ODI scores were analyzed one day after surgery and at last follow-up in each group using Wilcoxon signed-rank test in each group. The VAS score, ODI score, Farfan index, DHR and DHR rate were compared between the groups by means of the MannWhitney U test at last follow-up.

\section{Results}

We retrospectively analyzed 283 patients, and 159 patients were excluded from the study. The remaining 124 patients were then classified into two groups: group A contained 20 patients with IDL, and group

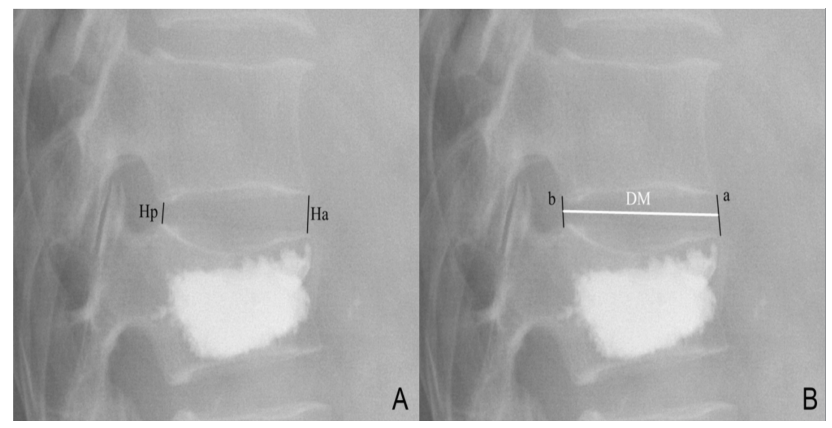

Fig. 1. Measurement of disc height (A) and disc diameter (B). Anterior disc height $(\mathrm{Ha})$ and posterior disc height $(\mathrm{Hp})$ were the shortest distances between the anterior and posterior edges of the neighboring endplates, respectively. Lines a and $b$ (black lines) were drawn from the anterior and posterior endpoints of the superior vertebral endplate to the inferior, respectively. Disc diameter (DM, white line) was measured between the midpoints of line $a$ and $b$.
B included 104 patients without IDL. A total of 21 males and 103 females were included, with an average age of $65.52 \pm 8.10$ years (range from 50 to 84 ). The mean follow-up time was $20.56 \pm 3.51$ months. The distribution of IDL was as follows: 1 disc (level T10-T11), 6 discs (level T11-T12), 6 discs (level T12-L1), 5 discs (level L1-L2) and 2 discs (level L2-L3). The characteristics of the patients and fractured vertebrae, stratified by the presence or absence of IDL, were summarized in Table 1 . The total cement volume, which was $5.78 \pm 0.80 \mathrm{ml}$ in group A and $5.08 \pm 0.97 \mathrm{ml}$ in group $\mathrm{B}$, showed a statistically significant difference between the groups $(\mathrm{P}=0.003)$. No other statistically significant differences were detected between the groups.

\begin{tabular}{|c|c|c|c|}
\hline & $\begin{array}{r}\text { With Intradiscal } \\
\text { Leakage }(n=20)\end{array}$ & $\begin{array}{r}\text { Without Intradiscal } \\
\text { Leakage }(n=104)\end{array}$ & $\begin{array}{r}\mathbf{P} \\
\text { value }\end{array}$ \\
\hline \multicolumn{4}{|l|}{$\begin{array}{l}\text { Patient } \\
\text { characteristics }\end{array}$} \\
\hline Age, year & $64.20 \pm 8.024$ & $65.78 \pm 8.13$ & .427 \\
\hline Sex, female & $17 / 20$ & $86 / 104$ & 1.000 \\
\hline BMD (T-score) & $-2.88 \pm 0.44$ & $-2.72 \pm 0.39$ & .105 \\
\hline History of smoking & $3 / 20$ & $15 / 104$ & 1.000 \\
\hline $\begin{array}{l}\text { History of drinking } \\
\text { alcohol }\end{array}$ & $1 / 20$ & $11 / 104$ & .719 \\
\hline $\begin{array}{l}\text { Follow-up time, } \\
\text { months }\end{array}$ & $19.80 \pm 2.95$ & $20.71 \pm 3.61$ & .290 \\
\hline \multicolumn{4}{|l|}{$\begin{array}{l}\text { Fracture } \\
\text { characteristics }\end{array}$} \\
\hline Intravertebral cleft & $4 / 20$ & $8 / 104$ & .196 \\
\hline Fracture age, wk & & & .365 \\
\hline$\leq 6$ & 14 & 83 & \\
\hline $6-12$ & 4 & 12 & \\
\hline$\geq 12$ & 2 & 9 & \\
\hline Fracture location & & & 1.000 \\
\hline $\begin{array}{l}\text { Thoracolumbar } \\
\text { region (T11-L2) }\end{array}$ & 18 & 92 & \\
\hline $\begin{array}{l}\text { Lower lumbar } \\
\text { region (L3-L5) }\end{array}$ & 2 & 12 & \\
\hline Fracture type & & & .480 \\
\hline Wedge & 14 & 85 & \\
\hline Biconcave & 4 & 12 & \\
\hline Crush & 2 & 7 & \\
\hline $\begin{array}{l}\text { Fracture severity } \\
\text { grade }(\%)\end{array}$ & & & .428 \\
\hline$\leq 25$ & 7 & 43 & \\
\hline $25-40$ & 8 & 44 & \\
\hline$\geq 40$ & 5 & 17 & \\
\hline Endplate fracture & & & .078 \\
\hline absence & 2 & 30 & \\
\hline presence & 18 & 74 & \\
\hline \multicolumn{4}{|l|}{$\begin{array}{l}\text { Surgical } \\
\text { characteristics }\end{array}$} \\
\hline $\begin{array}{l}\text { Total PMMA } \\
\text { volume, } \mathrm{ml}\end{array}$ & $5.78 \pm 0.80$ & $5.08 \pm 0.97$ & $.003^{*}$ \\
\hline
\end{tabular}


Preoperative modified Pfirrmann disc grades showed no statistically significant differences $(\mathrm{P}=0.799)$. As shown in Table 2, 90\% of the corresponding discs in group A and $83.7 \%$ in group B were classified as grade 3 or grade 4 . Furthermore, the baseline Ha, Hp, DM and Farfan Index showed no statistically significant differences between the groups $(\mathrm{P}>0.05)$.

The Ha, Hp and Farfan Index significantly decreased in both groups (Table 3). At last follow-up, the anterior disc heights were significant different between the groups.

The Farfan Indexes were also statistically significant Table 2. Baseline disc characteristics.

\begin{tabular}{|c|c|c|c|}
\hline & $\begin{array}{r}\text { With Intradis- } \\
\text { cal Leakage } \\
(\mathbf{n}=\mathbf{2 0})\end{array}$ & $\begin{array}{r}\text { Without Intradis- } \\
\text { cal Leakage } \\
(n=104)\end{array}$ & $\begin{array}{r}P \\
\text { value }\end{array}$ \\
\hline $\begin{array}{l}\text { Preoperative modified Pfir- } \\
\text { rmann disc grade }\end{array}$ & & & .799 \\
\hline Grade 1 & 0 & 0 & \\
\hline Grade 2 & 1 & 10 & \\
\hline Grade 3 & 14 & 68 & \\
\hline Grade 4 & 4 & 19 & \\
\hline Grade 5 & 1 & 7 & \\
\hline $\begin{array}{l}\text { Baseline anterior disc } \\
\text { height, } \mathrm{mm}\end{array}$ & $8.11 \pm 2.50$ & $8.49 \pm 3.23$ & .865 \\
\hline $\begin{array}{l}\text { Baseline posterior disc } \\
\text { height, } \mathrm{mm}\end{array}$ & $4.24 \pm 1.15$ & $4.19 \pm 1.92$ & .194 \\
\hline Baseline disc diameter, $\mathrm{mm}$ & $38.75 \pm 4.57$ & $40.71 \pm 4.30$ & .066 \\
\hline Baseline Farfan index (\%) & $31.87 \pm 8.01$ & $30.51 \pm 8.77$ & .521 \\
\hline
\end{tabular}

different between the groups $(22.68 \pm 7.20 \%$ in group A vs. $26.63 \pm 8.12 \%$ in group $B, P=0.036$ ). The DHR was $9.19 \pm 2.89 \%$ in group $A$ and $3.88 \pm 2.70 \%$ in group $\mathrm{B}$, which was a statistically significant difference $(\mathrm{P}<0.01)$. The DHR rate, which also showed a statistically significant difference $(\mathrm{P}<0.01)$, was $29.39 \pm 7.90 \%$ and $12.75 \pm 8.18 \%$ in group $A$ and $B$, respectively (Figure 2).

The results of clinical efficacy are shown in Table 4. In both groups, the VAS and ODI scores improved significantly after surgery and maintained at last

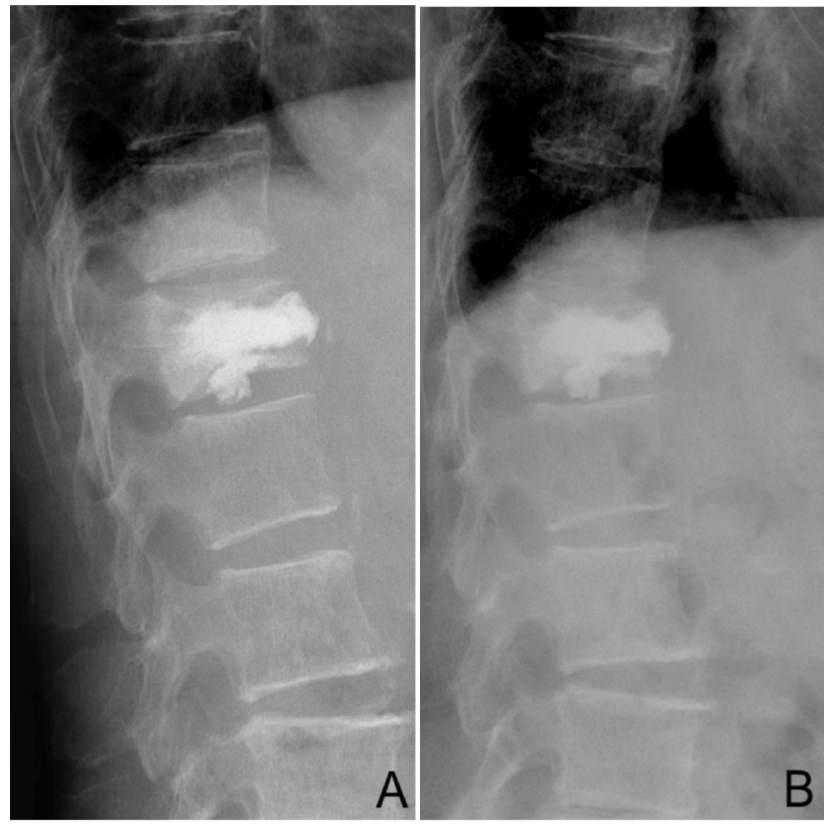

Fig. 2. A 70-year-old female who suffered from a vertebral compression fracture at T12. Lateral radiograph 19 months postoperatively (B) shows disc height reduction compared with the image one day after surgery (A) The Farfan index was $34.55 \%$ and $24.97 \%$ on lateral radiograph one day after surgery (A) and 19 months postoperatively (B), respectively.

Table 3. The results of disc height measurement.

\begin{tabular}{|c|c|c|c|c|c|c|c|c|c|c|c|c|c|c|}
\hline \multirow[t]{2}{*}{ Group } & \multicolumn{2}{|c|}{$\begin{array}{r}\text { Anterior disc height } \\
(\mathrm{mm})\end{array}$} & \multirow[b]{2}{*}{$\mathrm{P}$} & \multicolumn{2}{|c|}{$\begin{array}{r}\text { Posterior disc height } \\
(\mathrm{mm})\end{array}$} & \multirow[b]{2}{*}{$\mathrm{P}$} & \multicolumn{2}{|c|}{ Disc diameter (mm) } & \multirow[b]{2}{*}{$\mathrm{P}$} & \multicolumn{2}{|c|}{ Farfan index $(\%)$} & \multirow[b]{2}{*}{$\mathrm{P}$} & \multirow[t]{2}{*}{ DHR } & \multirow[t]{2}{*}{$\begin{array}{r}\text { DHR rate } \\
(\%)\end{array}$} \\
\hline & Post & Last & & Post & Last & & Post & Last & & Post & Last & & & \\
\hline $\begin{array}{l}\text { With In- } \\
\text { tradiscal } \\
\text { Leakage }\end{array}$ & $8.11 \pm 2.50$ & $5.62 \pm 2.11$ & $<0.001$ & $4.24 \pm 1.15$ & $2.92 \pm 0.93$ & $<0.001$ & $38.75 \pm 4.57$ & $38.77 \pm 4.64$ & 0.881 & $31.87 \pm 8.01$ & $22.68 \pm 7.20$ & $<0.001$ & $9.19 \pm 2.89$ & $29.39 \pm 7.90$ \\
\hline $\begin{array}{l}\text { Without } \\
\text { Intradiscal } \\
\text { Leakage }\end{array}$ & $8.49 \pm 3.23$ & $7.39 \pm 2.99$ & $<0.001$ & $4.19 \pm 1.92$ & $3.66 \pm 1.75$ & $<0.001$ & $40.71 \pm 4.30$ & $40.66 \pm 4.31$ & $<0.001$ & $30.51 \pm 8.77$ & $26.63 \pm 8.12$ & $<0.001$ & $3.88 \pm 2.70$ & $12.75 \pm 8.18$ \\
\hline $\begin{array}{l}\text { Between } \\
\text { Group P }\end{array}$ & 0.865 & 0.006 & & 0.194 & 0.096 & & 0.102 & 0.128 & & 0.283 & 0.036 & & $<0.001$ & $<0.001$ \\
\hline
\end{tabular}

Abbreviations: pos, one day after surgery (baseline); last, last follow-up; DHR, disc height reduction; DHR rate, disc height reduction rate. 
follow-up. In addition, there were no statistically significant differences between the groups $(\mathrm{P}=0.253$ and $\mathrm{P}=0.122$, respectively).

\section{Discussion}

Disc height is a parameter known to be correlated with the amount of disc degeneration. ${ }^{17-28}$ Measurement of disc height with Farfan's method has been proven to be reliable and to have very low intra- and inter-observer errors. Disc height reduction may be the result of aging, smoking, osteoporosis, endplate fracture or other factors. Thus, we evaluated these factors preoperatively, as shown in Table 1; no statistically significant differences in these factors were identified. Furthermore, the degree of degeneration of preoperative corresponding discs was evaluated, and no statistically significant difference was found between the groups $(\mathrm{P}=0.799)$.

In our study, we found that the cement volume in group A was larger than that in group B. A larger volume is more likely to result in extravasations. Most leakages are asymptomatic; however, some of the leakages may cause radicular pain, spinal cord compression or even pulmonary embolism. During our operation, if intradiscal cement leakage was noted, the injection was stopped immediately. After the cement hardened for several minutes, the injection continued if the fractured vertebra was not adequately filled.

With an average of 20 months of follow-up, we found that disc height reduction occurred in both groups. Kyphoplasty was used to stabilize the fractured ver- tebrae with an injection of cement into the vertebral body, which may have damaged the main route of nutrition supply to the adjacent disc. Furthermore, the stiffer PMMA within vertebral body reduces the physiologic inward bulging of the endplates of augmented vertebrae and increases the adjacent intradiscal pressure. Thus, the adjacent discs are unhealthy, and varying degrees of height reduction may occur after kyphoplasty. However, the reduction in group A was significantly larger than that in group B. According to previous studies, disc degeneration should be interpreted as when the disc height reduction rate is approximately $20 \%$ on standard lateral X-ray films. This verifies our hypothesis that cement leakage into the adjacent disc is associated with adjacent cementcontaining disc degeneration.

The space occupying effect of PMMA within the disc increases the intradiscal pressure. Sonmez et al. ${ }^{29}$ reported a case that developed lumbar disc herniation after PVP (percutaneous vertebroplasty) accompanied by IDL. The authors stated that intradiscal PMMA increased the intradiscal pressure and accelerated the degenerative process. The exothermic reaction during PMMA polymerization is a potential danger to discs or posterior neural structures if PMMA leaked. Lai et al. ${ }^{30}$ found that cement that leaked into the spinal canal significantly increased the temperature of the posterior cortex of porcine vertebral bodies in vitro. Belkoff et al. ${ }^{31}$ reported that the internal vertebral body temperature elevation that occurred during the polymerization of PMMA was sufficiently high to pose a risk of thermal injury to the surrounding tissues. Furthermore, the heat produced by PMMA polymerization in adjacent discs was not

Table 4. Clinical assessment using visual analog scale and Oswestry Disability Index.

\begin{tabular}{|l|l|l|l|}
\hline & & $\begin{array}{l}\text { With Intradiscal Leakage } \\
(\mathbf{n = 2 0})\end{array}$ & $\begin{array}{l}\text { Without Intradiscal Leakage } \\
(\mathbf{n}=\mathbf{1 0 4})\end{array}$ \\
\hline \multirow{2}{*}{ Visual analogue scale } & preoperative & $7.15 \pm 0.93$ & $7.17 \pm 1.04$ \\
\cline { 2 - 4 } & pos & $2.30 \pm 0.73$ a & $2.36 \pm 0.84$ a \\
\hline \multirow{2}{*}{ Oswestry disability index } & last & $2.80 \pm 0.62$ a & $69.90 \pm 13.69$ \\
\hline & preoperative & $73.80 \pm 12.31$ & $27.23 \pm 5.91$ a \\
\cline { 2 - 4 } & pos & $28.50 \pm 4.35$ a & $29.25 \pm 4.69$ a \\
\hline & last & $30.90 \pm 3.28$ a & \\
\hline
\end{tabular}

Abbreviations: pos, one day after surgery; last, last follow-up. aCompared with preoperative: $\mathrm{P}<0.05$

Downloaded from http://ijssurgery.com/ by guest on April 26, 2023 
easy to dissipate from venous circulation due to the avascularity of adult intervertebral discs. Certainly, the cytotoxity effect of PMMA monomers should not be neglected, as reported by Lazary. ${ }^{32}$ The intradiscal toxic monomers and PMMA debris may inhibit the viability of disc cells and promote apoptosis or necrosis of disc cells.

Our study shows that IDL and the resulting disc height reduction do not weaken clinical efficacy. It is in agreement with previous studies. Schulte et al. ${ }^{8}$ and Miyakoshi et al. ${ }^{10}$ concluded that DHR in segments adjacent to lumbar fusion were not correlated with clinical outcome. Mirovsky et al. ${ }^{5}$ reported that IDL was not found to affect clinical efficacy within two years of follow-up after vertebroplasty. Though the clinical efficacy is not weakened at an early stage, as shown in our study, the long-term results remain uncertain, especially considering the gradually reduced disc height and aggravated disc degeneration.

There are several limitations in our study, though the inclusion and exclusion criteria were strict. First is the lack of postoperative MRI examination due to its high cost and inconvenience for older patients. MRI is considered a better method to detect disc degeneration at early stages, which may not present disc height reduction on radiographs. ${ }^{33}$ Combining MRI with radiographs may be more accurate in reflecting disc degeneration in future studies. Second, this is a retrospective study. Further prospective and wellcontrolled studies with larger sample sizes are needed to investigate the overall effects of IDL on local spinal segments.

\section{Acknowledgements}

This research was funded by Jiangsu Provincial Special Program of Medical Science, China

(BL2012004).

\section{References}

1. Wardlaw D, Cummings SR, Van Meirhaeghe J, et al. Efficacy and safety of balloon kyphoplasty compared with non-surgical care for vertebral compression fracture (FREE): a randomised controlled trial.
Lancet. 2009; 373:1016-24.

2. Klazen CA, Lohle PN, de Vries J, Jansen FH, et al. Vertebroplasty versus conservative treatment in acute osteoporotic vertebral compression fractures (Vertos II): an open-label randomised trial. Lancet. 2010; 376:1085-92.

3. Yeom JS, Kim WJ, Choy WS, et al. Leakage of cement in percutaneous transpedicular vertebroplasty for painful osteoporotic compression fractures. J Bone Joint Surg Br. 2003; 85B:83-89.

4. Hulme PA, Krebs J, Ferguson SJ, et al. Vertebroplasty and kyphoplasty: a systematic review of 69 clinical studies. Spine. 2006; 31:1983-2001.

5. Mirovsky Y, Anekstein Y, Shalmon E, et al. Intradiscal cement leak following percutaneous vertebroplasty. Spine. 2006; 31:1120-1124.

6. Nieuwenhuijse MJ, Putter H, van Erkel AR, et al. New Vertebral Fractures after Percutaneous Vertebroplasty for Painful Osteoporotic Vertebral Compression Fractures: A Clustered Analysis and the Relevance of Intradiskal Cement Leakage. Radiology. 2013; 266:862-870.

7. Qian J, Yang H, Jing J, et al. The early stage adjacent disc degeneration after percutaneous vertebroplasty and kyphoplasty in the treatment of osteoporotic VCFs. PLoS One. 2012; 7:e46323.

8. Schulte TL, Leistra F, Bullmann V, et al. Disc height reduction in adjacent segments and clinical outcome 10 years after lumbar 360 degrees fusion. Eur Spine J. 2007; 16:2152-2158.

9. Berlemann U, Gries NC, Moore RJ. The relationship between height, shape and histological changes in early degeneration of the lower lumbar discs. Eur Spine J. 1998; 7:212-217.

10. Miyakoshi N, Abe E, Shimada Y, et al. Outcome of one-level posterior lumbar interbody fusion for spondylolisthesis and postoperative intervertebral disc degeneration adjacent to the fusion. Spine. 2000; 25:1837-1842.

11. Shi J, Mei X, Liu J, et al. The influence of correction loss in thoracolumbar fractures treated by posterior instrumentation: a minimum 7-year followup. J Clin Neurosci. 2011; 18:500-503.

12. Pfirrmann CW, Metzdorf A, Elfering A, et al. Effect of aging and degeneration on disc volume and shape: A quantitative study in asymptomatic volunteers. J Orthop Res. 2006; 24:1086-1094. 
13. Kumar MN, Jacquot F, Hall H. Long-term follow-up of functional outcomes and radiographic changes at adjacent levels following lumbar spine fusion for degenerative disc disease. Eur Spine J. 2001; 10:309-313.

14. Oner FC, van der Rijt RR, Ramos LM, et al. Changes in the disc space after fractures of the thoracolumbar spine. J Bone Joint Surg Br. 1998; 80:833-839.

15. Wang J, Zhou Y, Zhang ZF, et al. Radiological study on disc degeneration of thoracolumbar burst fractures treated by percutaneous pedicle screw fixation. Eur Spine J. 2013; 22:489-494.

16. Muller U, Berlemann U, Sledge J, et al. Treatment of thoracolumbar burst fractures without neurologic deficit by indirect reduction and posterior instrumentation: bisegmental stabilization with monosegmental fusion. Eur Spine J. 1999; 8:284-289.

17. Griffith JF, Wang YX, Antonio GE, et al. Modified Pfirrmann grading system for lumbar intervertebral disc degeneration. Spine. 2007; 32:E708-712. 18. Zou J, Mei X, Gan M, et al. Is kyphoplasty reliable for osteoporotic vertebral compression fracture with vertebral wall deficiency? Injury. 2010; 41:360-364.

19. Genant HK, Wu CY, van Kuijk C, et al. Vertebral fracture assessment using a semiquantitative technique. J Bone Miner Res. 1993; 8:1137-1148. 20. Yu CW, Hsu CY, Shih TT, et al. Vertebral osteonecrosis: MR imaging findings and related changes on adjacent levels. AJNR Am J Neuroradiol. 2007; 28:42-47.

21. Farfan HF, Henry F. Mechanical disorders of the low back. Lea \& Febiger Philadelphia,1973.

22. Pope MH, Hanley EN, Matteri RE, et al. Measurement of intervertebral disc space height. Spine. 1977; 2:282-286.

23. Battie MC, Videman T, Gill K, et al. Smoking and lumbar intervertebral disc degeneration: an MRI study of identical twins. Spine.1991; 16:1015-1021. 24. Baron YM, Brincat MP, Calleja-Agius J, et al. Intervertebral disc height correlates with vertebral body T-scores in premenopausal and postmenopausal women. Menopause Int. 2009; 15:58-62. 25. Lador R, Dreiangel N, Ben-Galim PJ, et al. A pictorial classification atlas of cement extravasation with vertebral augmentation. Spine J. 2010;
10:1118-27.

26. Ogata $K$, Whiteside LA. Nutritional pathways of the intervertebral disc. An experimental study using hydrogen washout technique. Spine. 1981; 6:211-216.

27. Polikeit A, Nolte LP, Ferguson SJ. The effect of cement augmentation on the load transfer in an osteoporotic functional spinal unit: finite-element analysis. Spine. 2003; 28:991-996.

28. Baroud G, Heini P, Nemes J, et al. Biomechanical explanation of adjacent fractures following vertebroplasty. Radiology. 2003; 229:606-607; author reply 607-608.

29. Sonmez E, Yilmaz C, Caner H. Development of lumbar disc herniation following percutaneous vertebroplasty. Spine. 2010; 35:E93-95.

30. Lai PL, Tai CL, Chen LH, et al. Cement leakage causes potential thermal injury in vertebroplasty.

BMC Musculoskelet Disord. 2011; 12:116.

31. Belkoff SM, Mathis JM, Jasper LE, et al. The biomechanics of vertebroplasty. The effect of cement volume on mechanical behavior. Spine. 2001; 26:1537-1541.

32. Lazary A, Speer G, Varga PP, et al. Effect of vertebroplasty filler materials on viability and gene expression of human nucleus pulposus cells. J Orthop Res. 2008; 26:601-607.

33. Luoma K, Vehmas T, Riihimaki H, et al. Disc height and signal intensity of the nucleus pulposus on magnetic resonance imaging as indicators of lumbar disc degeneration. Spine. 2001; 26:680-686.

\section{Disclosures}

This research was funded by Jiangsu Provincial Special Program of Medical Science, China

(BL2012004).

\section{Corresponding Author}

Huilin Yang, MD, the Department of Orthopaedics, The First Affiliated Hospital of Soochow University, 188 Shizi St, Suzhou, Jiangsu, China 215006. suzhouspine@163.com.

Published 5 October 2016.

This manuscript is generously published free of charge by ISASS, the International Society for the 
Advancement of Spine Surgery. Copyright @ 2016

ISASS. To see more or order reprints or permissions, see http://ijssurgery.com. 